\title{
The Cutter incident and the development of a Swedish polio vaccine, 1952-1957
}

\author{
Per Axelsson (*) \\ $\left(^{*}\right) \quad$ Centre for Sami Research, Umeå University, Sweden. \\ per.axelsson@cesam.umu.se
}

Dynamis

[0211-9536] 2012; $32(2): 311-328$

Fecha de recepción: 15 de septiembre de 2011

Fecha de aceptación: 9 de noviembre de 2011

SUMMARY: 1.-Introduction. 2.-The long detour. 2.1.-Swedish polio vaccine research. 2.2.-Vaccine procedures. 2.3.-A Swedish inactivated polio vaccine. 3.-The Cutter incident. 3.1.-The disappearance of Swedish polio epidemics. 4.-Concluding remarks.

ABSTRACT: The creation of two different vaccines to eradicate polio stands out as one of modern science most important accomplishments. The current article examines Swedish polio vaccine research, the vaccination campaign and especially how the Cutter incident came to affect Swedish Science, scientists and society in the 1950s. Sweden is one of the few countries that came to produce its own inactivated polio vaccine (IPV) in the 1950s, a type of vaccine they never abandoned. This article highlights the sometimes conflicting approaches between medical science on one hand and media and public on the other. The Swedish researchers did not agree with Jonas Salk's methods for producing a safe vaccine and had reserved attitudes when the Salk vaccine was announced, something that Swedish media disapproved of. After the Cutter incident media's representation of Swedish polio scientists became far more positive. The article also shows the development and distribution of a Swedish IPV and that contrary to some other countries Sweden did not doubt all American manufacturers and imported Salk IPV for the first polio vaccination campaign.

KEY WORDS: polio vaccine, Cutter incident, Sweden, Jonas Salk, Sven Gard.

PALABRAS CLAVE: vacuna de la polio, incidente Cutter, Jonas Salk, Sven Gard.

\section{Introduction}

Scandinavia was one of the first regions struck by polio epidemics in the late nineteenth century. By the early twentieth century it had become obvious that polio was to be part of the epidemiologic pattern of the peninsula for a long time ${ }^{1}$. Although polio cases were reported every year from 1905,

1. Paul, John. The history of poliomyelitis. New Haven and London: Yale University Press; 1971, p. 83. 
there was a decline after 1915 only to increase in the 1930s. Denmark and Sweden endured two of its worst epidemics in 1952 and $1953^{2}$ and if no prevention or cure was to be found, the future looked terrifying. During a meeting with the Swedish Medical Association in May 1954, the wellknown virologist and bacteriologist professor, Sven Gard, declared: «unless effective control measures are undertaken, we must expect a further increase in attack rates in the future» ${ }^{3}$.

Less than one year later, on 22 April 1955 in Ann Arbor, United States, surrounded by enthusiastic media an inactivated polio vaccine (IPV), produced by Dr. Jonas Salk, was declared as safe and effective ${ }^{4}$. In 1962 a second polio vaccine - the live attenuated polio vaccine (OPV) - was licensed and released for manufacture ${ }^{5}$. These two vaccines (although modified and improved since then) have successfully combated polio and today it is difficult to imagine a world without its positive effects. Less well known is that Sweden came to produce its own vaccine and went from being the country with the highest incidence rates in polio to be cleared from polio within seven years ${ }^{6}$. Since 1988 there has been a largely successful global effort to eradicate polio and recently there has been an intensified discussion of the final stages of the «polio endgame» 7 .

The creation of two different vaccines to eradicate polio stands out as one of modern science's most important accomplishments. For historians of medicine, the history of poliomyelitis mirrors and provides valuable perspectives concerning the development of modern medicine, science in general and national and international public health, all rounded off with an impressive gallery of authoritative personalities all devoted to finding a solution to stop polio epidemics. Many of these aspects are reinforced

2. Lassen, Henry C. A. The epidemic of poliomyelitis in Copenhagen, 1952. Proceeding of the Royal Society o Medoicine. 1954; 47 (1): 67-71. Axelsson, Per. Höstens Spöke. De svenska polioepidemiernas historia. Stockholm: Carlssons; 2004, p. 142. Author's translation.

3. Gard, Sven. Den hygieniska profylaxen. Nordisk Medicin. 1954; 52 (2): 1682-1685 (1685).

4. Oshinsky, David M. Polio. An American story. New York: Oxford University Press; 2006, p. 202213.

5. Paul, n. 1, p. 456.

6. Fagraeus, Astrid; Böttiger, Margaretha. Polio vaccination in Sweden. Review of Infectious Diseases. 1980; 2 (2): 274-276.

7. Aylward, Bruce; Yamada, Tadataka. The polio endgame. The New England Journal of Medicine. 2011; 364: 2273-2275. 
in the steadily growing academic and popular literature on the subject ${ }^{8}$. The fascination of the history of polio might also be attributed to the fact that there were several elements and incidents that halted and even could have reversed the successful outcome. The most intriguing and renowned has become known as the "Cutter incident» and concerns more than two hundred victims and eleven deaths caused by the IPV produced by the Cutter Laboratories in California. This debacle took place in April 1955, only two weeks after the IPV had been presented as «America's gift to the world $»{ }^{9}$. Instead of protecting against polio it gave the children polio. The Cutter incident did not only harm those exposed to the live polio vaccine, it halted the entire US programme for a brief period and it affected public trust in vaccines. As Paul Offit and others have shown it has had enduring effects on how the United States deal with pharmaceutical products. Cutter laboratories were responsible for the product and even if they had produced it to the best of their knowledge, they were «liable without fault» ${ }^{10}$. But the echo of the Cutter incident reached farther than the American continent. Historian Alison Day has described the profound effects that the incident

8. For international studies of the history of polio epidemics focusing on medical science and society, see, for example, Paul, n. 1. Gould, Tony. A summer plague, Polio and its survivors. New Haven and London: Yale University Press; 1995. Rogers, Naomi. Dirt and disease. Polio before FDR. New Brunswick: Rutgers University Press; 1992. Hardy, Anne. Poliomyelitis and the neurologists: the view from England 1896-1966. Bulletin of the History of Medicine. 1997; 71: 249-272. Grimshaw, Margret. Scientific specialization and the poliovirus controversy in the years before World War II. Bulletin of the History of Medicine. 1995; 69: 44-65. Rutty, Christopher. The middle-class plague: epidemic polio and Canadian State, 1936-1937. Canadian Bulletin of Medical History. 1996; 13: 277-314. Benison, Saul. Speculation and experimentation in early poliomyelitis research. Clio Medica. 1975; 10: 1-22. Benison, Saul. International medical cooperation: Dr. Albert Sabin, live poliovirus vaccine and the Soviets. Bulletin of the History of Medicine. 1982; 56: 460-483. Smith, Jane S. Patenting the sun. Polio and the Salk vaccine. New York: Anchor Books; 1990. Wyatt, Harold. V. Poliomyelitis. In: Kiple, Kenneth F. The Cambridge world history of human disease. Cambridge: Cambridge University Press; 1993, p. 943-950. Shell, Marc. Polio and its aftermath. The paralysis of culture. Cambridge: Harvard University Press; 2005. Smallman-Raynor, Matthew R.; Cliff, Andrew D., eds. Poliomyelitis: a world geography: emergence to eradication. Oxford: Oxford University Press; 2006. Axelsson, Per. «Do not eat those apples, they have been on the ground!»: polio epidemics and preventive measures, Sweden 1880-1940s. Asclepio. 2009; 51 (1): 23-37. Nathanson, Neal; Kew, M. Olen. From emergence to eradication: the epidemiology of poliomyelitis deconstructed. American Journal of Epidemiology. 2010; 172 (11): 1213-1229.

9. Oshinsky, n. 4, p. 215.

10. Offit, Paul A. The Cutter incident. How America's first polio vaccine led to the growing vaccine crisis. New Haven and London: Yale University Press; 2005, p. 132-153. 
had on the New Zealand polio immunisation programme ${ }^{11}$. Ulrike Lindner has illustrated how the Cutter incident helped make both West Germany and the United Kingdom abandon planned campaigns and turn away from IPV ${ }^{12}$.

By examining Swedish polio vaccine research, the vaccination campaign and especially how the Cutter incident came to affect Swedish science, scientists and society, this article aims to add another piece to the puzzle of polio history. It will start out by giving a background of the international research that led to the inactivated polio vaccine.

\section{The long detour}

As early as 1911, a confident and energetic Dr. Simon Flexner, the head of the young Rockefeller Institute, New York, was quoted as saying that they had learned how to prevent the disease and a cure «is not now far distant» ${ }^{13}$. Exactly what made him speak those words is unclear and still a cure for polio has never been achieved despite hopeful words from prominent scientists. In 1935 it appeared as though a vaccine was just around the corner when two different medical research teams, one in New York and the other in Philadelphia developed vaccines. Historians claim there was a competition between them which quickly led from carrying out trials on monkeys, to using the vaccine on themselves and later on children. The results from the New York vaccine trails that included 7,000 children and was led by Drs. Brodie and Park, indicated that it had very limited or no effects against the poliovirus ${ }^{14}$. The Philadelphia team, led by Dr. John Kolmer, tested its vaccine on 10,000 children and it had terrible results. Twelve persons got polio most likely from the vaccine and six of them died ${ }^{15}$. Researchers all over the world were most likely deterred by these fallouts because it took

11. Day, Alison. «An American tragedy». The Cutter incident and its implications for the Salk polio vaccine in New Zealand 1955-1960. Health and History. 2009; 11 (2): 42-61.

12. Lindner, Ulrike. Changing regulations and risk assessments: national responses to the introduction of inactivated polio vaccine in the UK and West Germany. In: Gradmann, Christoph; Simon, Jonathan, eds. Evaluating and standardizing therapeutic agents, 1890-1950. Hampshire: Palgrave Macmillan; 2010, p. 229-251.

13. Paul, n. 1, p. 116.

14. Offit, n. 10, p. 17.

15. Paul, n. 1, p. 261. 
fifteen years before polio vaccine research was seriously carried out again. But as David Oshinsky points out, «On one level, of course it had severely dampened expectation about the prospects of a safe and effective polio vaccine. On another level, however, it had fuelled curiosity of researchers about what had to be learned before proceeding again» ${ }^{16}$.

There have been numerous accounts of what final crucial steps were needed to be taken to achieve a safe and effective polio vaccine ${ }^{17}$. Usually three research findings occurring around 1950 are highlighted: 1) In 1949, Enders, Weller and Robbins, in Boston, revolutionised virology when they showed how to cultivate polio virus on tissues. This finding did not only save a huge number of monkeys, it also made it theoretically possible to -in a short amount of time- produce enough vaccine to provide to the parts in the world where polio appeared as an epidemic. This finding gave the three men the Nobel Prize in Medicine or Physics in $1954^{18}$. 2) In the mid 1940s it was made obvious that poliovirus was more than one virus. In 1948, researchers like Bodian and Howe at John Hopkins University, Salk in Pittsburgh and Paul and Trask at Yale tested a huge amount of strains and showed that poliovirus consisted of three different types. This was a crucial finding, since an effective vaccine would have to protect against all three types. 3) Polio virus was believed to not reach the blood but Dr. Dorothy Horstmann showed that the poliovirus could, in the early stages of infection, be found in the blood and that antibodies were formed and soon killed it (viremia). This indicated that a vaccine might be able to do the same ${ }^{19}$.

John Paul writes that around 1952 there were several research teams around the world that had begun to do experiments to find a vaccine against polio. «Hopes were running high, and the opinion was widespread that it might not be so difficult to prevent poliomyelitis after all» ${ }^{20}$. Building on the successes from Enders, Weller and Robbins, the American virus typing committee and the findings that polio virus travelled the blood in the early stages of infection, a Swedish team also began experiments to find a vaccine against polio.

\footnotetext{
16. Oshinsky, n. 4, p. 58.

17. The most thorough work explaining events in polio research is still: Paul, n. 1 .

18. Norrby, Erling; Prusiner, Stanley B. Polio and Nobel Prizes: Looking back 50 years. Annals of Neurology. 2007; 61: 385-395.

19. Oshinsky, n. 4, p. 125-127.

20. Paul, n. 1, p. 417.
} 


\subsection{Swedish polio vaccine research}

The initiative to produce a Swedish vaccine was set up in 1952 by professors Sven Gard, Gunnar Olin, and Tore Wesslén ${ }^{21}$. They put together a working group that consisted of ten members from three different departments, all geographically located at Stockholm ${ }^{22}$. Gunnar Olin, was head of the State Bacteriologic Laboratory (SBL), and together with professor Gard he became the most well-known character in Swedish polio vaccine research. Gard said in an interview from the 1980s that during this period of his life, he was «breathing» polio research twenty-four hours a day ${ }^{23}$. Not only was he heavily involved in the vaccine research, he also served as member and chairman of the Swedish National Polio Organisation (today named: RTP) and was part of several international collaborations. The RTP was originally founded in 1946 by polio survivors but in 1949 the board decided to try and bring in "people in leading positions in society» to raise awareness and money to fight the disease and its consequences in Sweden. This became a successful strategy. Gard was asked to serve as chairman and several prominent persons became involved in the organisation. Fundraising became crucial and the RTP, together with Solstickan (Swedish Match), Aftonbladet (a Swedish newspaper) and Radiohjälpen (the Swedish state radio) succeeded well in its task and its funding came to support both polio survivors as well as polio vaccine research ${ }^{24}$.

There was, and had been for a long time, a great concern among the public to solve the ravaging polio epidemics. Sven Gard, Gunnar Olin and others were part of a long tradition of Swedish researchers devoted to deciphering the disease. Northern Sweden had been the scene of the world's first recorded epidemic of «Poliomyelitis anterior acuta» in $1881^{25}$. These early epidemics enabled Swedish medical science to become involved and early on acquire a leading role in international medical research on the disease. Karl-Oskar Medin, a paediatrician at the Karolinska Institutet in

21. Lundbäck, Holger. Vaccination mot polio. Läkartidningen. 1965; 62 (8): 618-623.

22. Gunnar Olin, Astrid Fagreus, Tore Wesslén, L. Heller, Erik Lycke and G. Wrange from SBL, Arne Svedmyr and L. Kjellén from Stockholms stads bakteriologiska laboratorium and Sven Gard and M. Uhler at the department for virus research, Karolinska Institutet, Stockholm.

23. Jakten på polioboven. Vetandets värld, Sveriges Radio P1, 26/05/1982. The National Archives for Sound and Picture, Stockholm (digitalized archive).

24. Axelsson, n. 2, p. 175-180.

25. Axelsson, n. 8. 
Stockholm, is famous for carrying out the first scientific examination of an ongoing polio epidemic in $1887^{26}$. Medin considered polio to be an acute infectious disease, affecting the nervous system, and able to cause epidemics. He presented these results at an international medical conference in Berlin in 1890 and a publication came out that same year ${ }^{27}$.

Medin's pupil, Dr. Ivar Wickman, carefully investigated and mapped more than one thousand victims in Sweden's first nation-wide epidemic in 1905. By mapping these cases of polio and personally visiting the homes of more than three hundred polio victims, Wickman concluded that polio was often spread by people who appeared to be healthy but nevertheless were affected by the disease. Wickman named these «abortive cases» and his theory on polio epidemiology was largely accepted by medical science by $1910^{28}$.

The methods used to investigate appearance of polio were, until Karl Landsteiner and Erwin Popper's discovery of the filterable virus in 1908, mainly based on clinical observation and epidemiological mapping. From 1910 onwards, science turned to the laboratory, and monkeys were used to explore the characteristics of polio. Simon Flexner, the head of the Rockefeller Institute, became a central figure in polio research ${ }^{29}$. Sweden also turned to the laboratory and established the SBL in 1909. The first head of the laboratory was Alfred Petterson but he was succeeded by Carl Kling in 1919 and he came to lead the SBL for almost three decades. In 1945 Kling stepped down in favor of Gunnar Olin who then led the laboratory into the period of polio vaccine production. Nevertheless, from the first days in 1910 until the SBL closed in 1993, polio was a main focus ${ }^{30}$.

\subsection{Vaccine procedures}

In a discussion at the Swedish Society of Medicine in May 1954, the grand old man of Swedish Bacteriology, Carl Kling, spoke and underlined that

\footnotetext{
26. John Paul devoted an entire chapter to Medin in his book. Paul, n. 1, p. 71-78.

27. Medin, Oskar. En epidemi af infantile paralysi. Hygiea. 1890; 52 (9): 657-668. See also: Axelsson, n. 2, p. 73 .

28. Smallman-Raynor; Cliff, n. 8, p. 95-102. Axelsson, n. 2, p. 78-80. Rogers, n. 8, p. 141-143.

29. Grimshaw, n. 8.

30. Winter, Carin. Statens Bakteriologiska Laboratorium 1909-1993. Stockholm: Statens Bakteriologiska laboratorium; 1993.
} 
«Sweden was marching alongside other nations» ${ }^{31}$. Earlier that evening, Sven Gard, Gunnar Olin, Tore Wesslén, and Arne Svedberg had spoken about the latest achievements in the progress of making a Swedish inactivated polio vaccine. They were optimistic but extremely cautious and Gunnar Olin highlighted that, although it looked like they soon might find a safe well-functioning vaccine, there were several obstacles that needed to be overcome along the way. One of the most problematic issues according to Olin was the media. «The publicity regarding the [vaccine research] is huge and often untrustworthy: newspapers often give the impression that the victory has already been won. That is just not true» ${ }^{32}$. It is fairly obvious that Olin was not only referring to the research being done in Sweden but also to research overseas and especially by Jonas Salk in Pittsburgh. Dr. Salk's research was often covered in Swedish papers as well. However the Swedish researchers were not convinced that Jonas Salk was heading the straight way. Olin emphasized that if Salk's current work gave encouraging results there was still an enormous task ahead to further evaluate the best way to produce a vaccine ${ }^{33}$.

The National Foundation for Infantile Paralysis funded between 1948 and 1962 five large international meetings devoted solely to poliomyelitis ${ }^{34}$. At its third meeting in Rome the making of the vaccine was the prime aim. At that meeting Sven Gard criticized Jonas Salk and the procedures with which he used to kill off the vaccine. Gard argued that when his team had tried to follow Salk's methods the virus was not always inactivated. He needed much more time to kill off the virus than the nine days Salk advocated, preferably twelve weeks ${ }^{35}$. Gard presented a research that suggested that Salk should change some of his methods and that other strains might be more appropriate to use when making a safe vaccine. Salk disagreed with Gard and argued that it was not a question of how to best inactivate the virus

31. Barnförlamningsprofylax. Svenska läkarsällskapets diskussion. Nordisk Medicin. 1954; 52 (2): 1387-1389 (1388).

32. Olin, Gunnar. Barnförlamningsprofylax, förutsättningar och möjligheter. Nordisk Medicin. 1954. 52 (2): 1689-1693 (1693).

33. Olin, n. 32.

34. Porras, María-Isabel; Báguena, María-José; Ballester, Rosa. Spain and the international scientific conferences on polio, 1940s-1960s. Dynamis. 2010; 30: 91-118.

35. Discussion panel. Poliomyelitis. Papers and discussions presented at the third international poliomyelitis conference. Philadelphia: J. B. Lippincott Company; 1955, p. 202-205. See also Offit, n. 10, 41-43. 
but more of what concentrations were chosen to produce the vaccine. Also, during the same session, the American virologist Albert Sabin advocated that a live attenuated vaccine would work much better than the inactivated vaccine that Salk was making ${ }^{36}$.

However, despite the criticism, Jonas Salk did not make the proposed changes in the inactivation methods and the largest human vaccine trial was underway in 1954. This trail went on for one year and in a very famous public announcement on 12 April 1955, Dr. Thomas Francis, who had led an independent committee to evaluate the trial, declared Salk's vaccine as safe, potent and effective. The licensing of the vaccine for commercial use was initiated immediately at the Laboratory of Biologics Control in Washington. The laboratory in Washington was not financed or staffed to be able to test each dose of vaccine when it had gone into mass production. They had to trust the companies (six American and one Canadian) that were licensed to make the vaccine. The vaccination began immediately in the USA as well as in Canada.

\subsection{A Swedish inactivated polio vaccine}

Historian David Oshinsky has done a magnificent job in describing the scenes of victory (and the circus) surrounding the dates of the release of the vaccine, where Salk instantly became a national hero. Jonas Salk had conquered polio. Few researchers have been able to repeat his public success ${ }^{37}$. The good news travelled fast and reached the Swedish people through radio and newspapers published on 14 April 1955. That day Swedish newspapers had headlines bearing remembrance of successful war victories, «Polio conquered ${ }^{38}$, «Victory over death and suffering ${ }^{39}$, «An enemy of the people defeated ${ }^{40}$ and "Triumph for science» ${ }^{41}$. One of the newspapers even suggested that the 12th of April should become a

\footnotetext{
36. Discussion panel, n. 35.

37. Oshinsky, n. 4, p. 214-216.

38. Svenska Dagbladet. 13 Apr 1955.

39. Piteåtidningen. 14 Apr 1955.

40. Östgöten. 14 Apr 1955.

41. Folket. 14 Apr 1955.
} 
national holiday ${ }^{42}$. The public demand was that the Salk vaccine needed to be bought and brought to Sweden immediately.

The Swedish experts in the field were also interviewed. Professor Gard did not share the massive appraisal of Salk's achievement and adopted an attitude of reserve. Gard said on the Swedish national radio that he wanted to wait before ordering the Salk vaccine, until he had carefully read the scientific report. At that point in time, the largest Swedish tabloids interpreted this as envy of the fact that Salk had presented a vaccine before Gard and the Swedish medical team ${ }^{43}$. The large tabloid Expressen commented on the $14^{\text {th }}$ of April that «a touch of envy has unfortunately become visible among the Swedish researchers, especially professor Sven Gard's comments regarding the Salk vaccine» ${ }^{44}$.

Few outside of Sweden may be aware that only seven days after Salk's triumph, on 19 April 1955, Gard and Olin presented a Swedish polio vaccine. This particular research had been made possible by grants from Kung Gustav V Åttio-årsfond and the RTP. The vaccine was an inactivated vaccine but different from Salk's in several ways. It was inactivated at other temperatures, Gard and Olin did not use the same virus strains Salk had used and theirs were grown in tissue from human embryos. While Salk had used monkeys, the Swedish vaccine had first been tested on guinea pigs and rabbits and later on humans, although it was not such an enormous human trial as Salk's ${ }^{45}$. During the spring of 1954, the researchers had planned to vaccinate school children in four different grades in twelve Swedish counties [län], but settled with 2.000 children in Stockholm. The children had been selected during a scanning of immunity levels and those that lacked immunity to all or two of the three virus types were chosen ${ }^{46}$. The Swedish Royal Medical Board [Kungliga Medicinalstyrelsen] decided to use the Swedish vaccine for the upcoming vaccinations that were scheduled to begin in the spring. Nevertheless, it was considered important to import American Salk

\footnotetext{
42. Nyheterna. 16 Apr 1955.

43. Aftonbladet. 16 Apr 1955.

44. Expressen. 14 Apr 1955.

45. Olin, n. 32, p. 1689-1693.

46. Gard, Sven. Poliomyelitis vaccine studies in Sweden. Bruxelles: Association Européenne contre la Poliomyélite; vol. 3, 1956, p. 24-29. Olin, n. 32.
} 
vaccine as the Medical Board stated that the Swedish vaccine would not be enough to inoculate the three age groups as had been planned ${ }^{47}$.

\section{The Cutter incident}

On 28 April 1955, Swedish media reported the news of the Cutter incident. Sven Gard and the other Swedish polio researchers had not been informed much earlier. However, David Oshinsky shows that reports of polio victims started to arrive on the 24th of April and that American scientists met confidentially two days later in Washington, United States, to discuss the vaccine related cases and to find ways to limit the damage ${ }^{48}$. Two weeks later, on the 6th of May, Leonard Scheele, U.S. surgeon general, halted the American campaign to further investigate all vaccine producing companies. It was soon concluded that the Cutter laboratories bore sole responsibility for all cases and the American IPV campaign resumed in late May. Still, Paul Offit has showed that yet another company, Wyeth, caused several cases of polio in the first weeks of vaccination. An expert report by Neal Nathanson described 37 vaccine associated cases. However, the report of the «Wyeth problem» was only known to a handful of people and never released to the media, public health officers or polio vaccine advisers ${ }^{49}$.

Events in Sweden unfolded differently. Only two days after the Cutter incident was publically released, on the 30th of April, the Medical Board decided that Swedish children would not be vaccinated with either the Swedish or the American vaccine. It is worth noting that this was more than a week before the Americans halted their campaign. The major reason for not using the Swedish vaccine was that Gard, Olin, and their research team had difficulties in interpreting one of the control tests and the incidents taking place in the USA came to be seen as confirmation that further tests were needed to make sure not to repeat a similar incident on Swedish soil ${ }^{50}$. Professors Gard and Olin were quoted in the media as saying that, with the American Cutter events unfolding, the Swedish population had also

47. Kommuniké till TT ang det svenska polioympämnet. National Archives, Stockholm Medicinalstyrelsensarkiv. Hälsovårdsbyrån,. FXXXXVIII, Poliofrågor 1953-1956.

48. Oshinsky, n. 4, p. 221-222.

49. Offit, n. 10, p. 102-103.

50. Kungl. Majt:ts [Royal Majestys] proposition nr 91. Stockholm. 1956. 
become aware of the dangers of the vaccine ${ }^{51}$. An interesting shift in the treatment of Swedish scientists can be observed in the media, illustrated below by a quote from the liberal tabloid Göteborgsposten:

«The somewhat subdued statements made in this country were interpreted in some places as jealousy over that the Americans arrived first, because our researchers also found themselves standing at the finish line. But they spoke out of wisdom, based on the knowledge of how infinitely careful you have to be and how many risks and errors there are. That their caution has been entitled has now quickly been confirmed, and the insinuations against our scientists, that they might have certain ulterior motives, have lost its sting» ${ }^{52}$.

The Cutter incident clearly marked a turnaround of opinion, especially for Gard who until that point had been the one most criticized by the Swedish media. He was now declared an outstanding scientist who had foreseen the incident. Gard's status also seemed to increase internationally as he later became elected president of the Association Européenne contre la Poliomyélite. In other words, even if the Cutter incident was a setback to the polio vaccination and devastated the lives of many Americans, in Sweden it seemed to have restored some of the public faith in Swedish researchers committed to finding a safe polio vaccine. When Gard officially called off the national vaccination campaign on 1 May 1955, there were no complaints in the media. At that point, it was evident that polio was not yet conquered.

Immediately after the decision to suspend the 1955 vaccination new plans for the following spring were designed. Further testing of the Swedish vaccine was needed and the time frame also gave a possibility of producing enough vaccine for Sweden not to have to import American vaccine. However, in January 1956 the Medical Board announced that a nationwide vaccination would not be carried through. It was still assumed that, during the spring, vaccination would be made possible on a limited scale. In letters circulating between Olin and the Medical Officer of Health, Rolf Bergman, thirteen counties were included in the plans but at the end of February 1956 there were only six. In the planned vaccination Olin described that it intended to offer «inoculation of all children born on odd dates in any year 1945-

51. Expressen. 4 May 1955.

52. Göteborgstidningen. 28 Apr 1955. 
$1948 »^{53}$.There were also plans for utilizing control groups. Nevertheless, the 1956 polio vaccination campaign was cancelled some months later. This time around there was more disappointment among politicians and the media and there were reports that some Swedes had left for Denmark to get a shot of polio ${ }^{54}$. The scientists and Medical Board stood by their decision. It had become evident that the rebuilding and renovation of the SBL premises that were needed to make it suitable for vaccine production could not be completed in time for a large scale campaign ${ }^{55}$. In short, the SBL had not been able to produce enough vaccine and the Medical Board was not interested in importing American vaccine.

\subsection{The disappearance of Swedish polio epidemics}

Polio vaccination began in 1957 in Sweden. At that point neighboring Denmark had been vaccinating for two years and had almost managed to vaccinate their entire population. The Danes had used Salk methods to inactivate the virus but the vaccine was produced by the Danish State Serum Institute, a laboratory with no other end aim than public health ${ }^{56}$. Sweden used vaccine produced by the researchers at SBL and Karolinska Institute. However, they could not produce enough vaccine domestically and eventually the Medical Board decided to import from an American vaccine company, Eli Lilly and Company. During the 1957 vaccination campaign these two vaccines were carefully monitored, enabling researchers to keep track of which children received Swedish vaccine and which received the American vaccine. After the 1957 campaign Sweden used solely the Swedish IPV ${ }^{57}$.

On national radio on 7 January 1957 Gunnar Olin presented the benefits of inoculating children born between the years 1950 and 1953. He gave no guarantees that all those were vaccinated would not get polio, since some children might have been infected before vaccination. He informed that they were going to use both Swedish and imported American vaccine and the latter had been improved and 40 million children in the U.S. and Canada

\footnotetext{
53. Poliofrågor. Riksarkivet. n. 47.

54. Axelsson, n. 2, p. 153.

55. Winter, n. 30, p. 15.

56. Paul, n. 1, p. 436.

57. Fagreus; Böttiger, n. 6, p. 274.
} 
had been vaccinated without any reports of complications. Olin finished his «speech to the nation» with the words:

"Consider that it is a preventive measure only. When the epidemic has broken out, it is too late. It is now the decision has to be taken if You want Your Child to have the possibility of protection, given by this year's vaccine» ${ }^{58}$.

The vaccine campaign was set up and organized by the Medical Board. They had appointed regional leaders, namely each county's first provincial physician, and the doctors in charge of medical care in Stockholm, Gothenburg, Malmö and Helsingborg. The IPV was completely voluntary and free, and was done by school health services for school children and child care units for younger children who had not yet started school. Parents needed to sign a form allowing the treatment. The vaccine that was injected into the left upper arm was conducted with two treatments at least three weeks apart, which then would be reinforced by another injection after 7-12 months. The campaign was planned to run until the 30th of June when the «polio season» was at hand. To assess the efficacy of the vaccine a blood test was taken from a small number of schoolchildren ${ }^{59}$.

Concerning the polio vaccine campaign it became obvious in midJanuary 1957 that the interest in the vaccine had not entirely met the expectations of the Medical Board. In a letter to the regional leaders, Rolf Bergman announced that they should continue to ask parents to send their children for the polio vaccination to increase the effect of the campaign ${ }^{60}$.

Table 1 shows the number of people vaccinated until 1965. It also explains that 717.000 children were vaccinated in 1957 and that meant that the campaign reached 177.000 fewer children than the 900,000 than the Medical Board had hoped. Furthermore, Table 1 shows which age groups were first approached and how many cases with and without paralysis occurred during the period. It clearly illustrates how the virus, after some years of vaccination, stopped circulating in society thereby putting an end to polio epidemics in Sweden.

\footnotetext{
58. Axelsson, n. 2.

59. Axelsson, n. 2 .

60. Kungl. Medicinalstyrelsen [Royal Medical Board] Stockholm 3. D: $\mathrm{nr} 44 \mathrm{Hv} / 57$. Document owned by the author.
} 
Table 1. Reported polio cases, types of polio virus, vaccinations by age-group and number of new vaccinations, Sweden 1950-1965

\begin{tabular}{cccccc}
\hline Year & $\begin{array}{c}\text { Polio cases } \\
\text { with paralysis }\end{array}$ & $\begin{array}{c}\text { Polio cases } \\
\text { without } \\
\text { paralysis }\end{array}$ & Type Virus & $\begin{array}{c}\text { Vaccinated } \\
\text { by age group }\end{array}$ & $\begin{array}{c}\text { Number of new } \\
\text { vaccinations }\end{array}$ \\
\hline 1950 & 1164 & 540 & & & \\
1951 & 339 & 212 & & & \\
1952 & 363 & 129 & & & \\
1953 & 3029 & 2061 & $1,2,3$ & & \\
1954 & 544 & 455 & $1,2,3$ & & \\
1955 & 325 & 161 & $1,2,3$ & & \\
1956 & 248 & 301 & $1,2,3$ & & \\
1957 & 148 & 102 & $1,2,3$ & $4-11$ & 000 \\
1958 & 155 & 37 & $1,2,3$ & $4,13-15$ & 000 \\
1959 & 42 & 14 & $1,2,3$ & $2-26$ & 1000 \\
1960 & 15 & 3 & 1,2 & $1-40$ & 489000 \\
1961 & 64 & 60 & 1 & $1-51$ & 1093000 \\
1962 & 6 & 8 & 1,3 & $1-52$ & 641000 \\
1963 & 0 & 0 & & $1-53$ & 227000 \\
1964 & 0 & 1 & 2 & $1-54$ & 159000 \\
1965 & 1 & 1 & 1 & Everyone & 216000 \\
\hline
\end{tabular}

Source: Poliofrågor, Hälsovårdsbyrån, Medicinalstyrelsen, Riksarkivet, Stockholm.

There were a few reports of resistance to participation in the campaign. The County of Jönköping endured vaccine resistance that resulted in low participating rates at specific places. Nonetheless, the physician responsible for the entire county judged that it did not interfere with the overall good result of the region ${ }^{61}$. Although Sweden started two years later than countries like the USA, Denmark and Canada it was soon evident that the Swedish polio vaccine campaign was very successful. After a slow start it achieved close to $100 \%$ participation from the population. Several studies have confirmed that the Swedish IPV was also more potent than the American vaccine due to the fact that it used a different method to inactivate the virus. 1961 was the last year when poliovirus circulating in society caused an epidemic ${ }^{62}$. 
Most other countries later shifted from IPV to OPV. Sweden had minor trials using OPV and there were extensive plans to shift from IPV around 1963-64 ${ }^{63}$. In the end Sweden decided to remain faithful to the IPV and has been so ever since ${ }^{64}$.

\section{Concluding discussion}

What might we learn from the history of polio vaccine production? In the mid 1990s Harold V. Wyatt provided some answers in order to assist future vaccine research concerning infectious diseases, especially HIV and AIDS. He concluded that the history of polio vaccines has illustrated that therapy and immunization may have side effects and must be carefully tested, that errors may occur in the production and handling of the vaccine, that the same disease may occur in different ways in different parts of the world, that there may be some population groups with different susceptibility and response, that people's attitude to the vaccine can change and that the trials of therapies and immunization will fail until the correct theoretical starting points have been found ${ }^{65}$. We can all be supportive of Wyatt's conclusions although it unmistakeably carries an idea that a «real» theoretical foundation will always reveal itself. What if it never will?

Historians like Lindner and Blume have highlighted how commercial interests, national traditions, international relations, or global agendas influence not only countries' decision making, in using one vaccine over the other, but also the success of a vaccination campaign. Based on the fact that OPV never came to be used in Sweden, the Swedish experience could easily be argued to correspond well with Lindner and Blume's analysis of path dependency and vaccine production.

This article brings to the fore the role of the sometimes conflicting approaches between academic research, such as medicine, on one hand and the media and the public on the other. Historian Peter Sköld has showed that

63. Tallmo, Sigrid. Varför väljer WHO inte det säkraste poliovaccinet? Läkartidningen. 1999; 98 (48): 5343.

64. Pagano, Joseph S. et al. Chat type 1 attenuated poliovirus vaccine prepared on human diploid cells: a study in 135 Swedish children. Bruxelles: Association Européenne contre la Poliomyélite; vol. 8, 1963, p. 498-507.

65. Wyatt, n. 8, p. 943-950. 
the few contemporary Swedish newspapers, alongside doctors and priests, were all in support of smallpox vaccination when it was made available in the early 1800s. This soon made it a success. In order to perpetuate the effects of the smallpox vaccination, the Swedish state made it mandatory in $1815^{66}$. The role of the media was also evident when the vaccine haemophilus influenzae type b (Hib vaccine) was introduced in Sweden in the 1990s. Garpenholt (2000) showed that, for a successful vaccine campaign, the disease must be considered a clear threat, the vaccine needs to be recognized as safe and effective both among the population and physicians, the importance of distribution; people need to know where to go to get vaccinated, and that the media plays an important in publishing the news of cases of illness in $\mathrm{Hib}^{67}$. Concerning the polio vaccine, researchers and the media at one point ended up on different sides of the fence. They shared the same goal, of course: to get the Swedish population vaccinated before another big epidemic struck the country. Still the ideas of what constituted a safe vaccine varied in the media, the public and medical experts. I believe that both perspectives are understandable. Even after the Cutter incident, it was obvious to all that for instance Denmark and Canada did not cancel their campaigns and continued to use a vaccine based on Salk's method, without any problem. The Swedish people continued contracting polio during 1955 and 1956, so from a public point of view it was reasonable to question why Sweden did not want to import vaccine during those years. From the Swedish researchers' perspective it was, of course, a more complex matter.

One of the complicating factors may have been the many strong personalities in the international polio vaccine research of the 1950s. Sweden's leading polio researcher, Sven Gard, openly critiqued Jonas Salk and his choice of methods and materials for his vaccine. This critique was also evident in Gard's work within the Nobel Committee. Using the Nobel Archives, Erling Norrby and Stanley B. Prusiner recently published an exciting description of the work within this exclusive scientific milieu that they both know very well. Norrby and Prusiner shed light on a question asked many times; why was Salk never selected as Nobel laureate? Jonas Salk

66. Sköld, Peter. The key to success: The role of local government in the organization of smallpox vaccination in Sweden. Medical History. 2000; 45: 201-226.

67. Garpenholt, Örjan. Vaccination against Haemophilus influenzae type b in Sweden. Aspects of epidemiology, economy and the process of introduction. Linköping: Linköping University; 1999. 
was nominated for a Nobel Prize in Physiology or Medicine more than once, the first time in 1955. Every nominee has an evaluator and as a prominent member of the Nobel committee, Sven Gard evaluated Salk's work every time. 1956 Gard made an extended evaluation where he pointed out that Salk, in principal, had not contributed anything new to the field and had only exploited discoveries made by others. Gard underlined that some of Salk's working hypotheses in fact were incorrect and that it could not be excluded that the Cutter incident was a «result directly from his practical application of such incorrect hypotheses ${ }^{68}$. Needless to say, Gard's extended evaluation in 1956 made further Salk nominations fruitless.

Then again, as Ulrike Lindner showed, the Cutter incident came to create an international discussion of vaccine safety standards. Studying Britain and West Germany, Lindner concluded that national scientific cultures, along with how health officials and governments perceive other countries' safety standards, influenced the implementation of IPV ${ }^{69}$. Adding to that argument, Alison Day also highlighted how New Zealand medical authorities, after the Cutter incident, regarded all American produced IPV as below standard and unsafe. New Zealand however did believe that the IPV was useful and came to import Australian and British produced vaccine for their polio immunization programme ${ }^{70}$.

Contrary to New Zealand and Britain, the Swedish Medical Board, guided by the research team at SBL, did not doubt all American manufacturers and imported Salk IPV from Eli Lilly and Company for the first polio vaccination campaign. But they were not confident that the campaign would be without problems. The fear of repeating the Cutter incident on Swedish soil was apparent. This was also evident in the words of Olin's successor at SBL, Holger Lundbäck, who wrote that it required a lot of courage to give the green light to a Swedish IPV campaign in $1957^{71}$. With those words Lundbäck echoed all of his predecessors at the SBL and previous Swedish polio researchers. The scientific culture shaped by Medin, Wickman, Kling, Gard and Olin had always advocated a cautious approach.

\footnotetext{
68. Norrby; Prusiner, n. 18, p. 393.

69. Lindner, n. 12, p. 245-246.

70. Day, n. 11, p. 57-58.

71. Winter, n. 30, p. 15.
} 